\title{
ANTIMICROBIAL RESISTANCE OF AEROMONAS SPP. ISOLATED FROM THE SEA TROUT (SALMO TRUTTA L.) IN LATVIA
}

\author{
Olga Revinaa, ${ }^{1,2}$ Jel̦ena Avsejenko ${ }^{1}$, Dina Cīrule ${ }^{1}$, Anda Valdovska ${ }^{2}$ \\ ${ }^{1}$ Institute of Food Safety, Animal Health and Environment BIOR, Latvia \\ ${ }^{2}$ Latvia University of Agriculture \\ olga.revina@bior.lv; jelena.avsejenko@bior.lv; dina.cirule@bior.lv; anda.valdovska@1lu.lv
}

\begin{abstract}
The aim of this study was to investigate the patterns of antibiotic resistance of Aeromonas spp. bacteria isolated from the sea trout (Salmo trutta) from the state fish hatcheries of the Institute of Food Safety, Animal Health and Environment 'BIOR', Latvia.

Bacteriological investigations were performed at four state fish hatcheries located in the drainage basins of the main Latvian rivers - Daugava, Venta and Gauja, during the five-year period $(2012$ - 2016). In fish with visible clinical signs, bacteriological samples were collected from heart, liver, spleen, kidney and ulcer surfaces.

Aeromonas hydrophila and Aeromonas salmonicida were isolated from sea trouts. A total of 52 individual sea trouts were examined.

Resistance to amoxicillin, ampicillin, cephalexin, colistin, doxycycline, enrofloxacin, erythromycin, florfenicol, gentamycin, kanamycin, lincomycin, neomycin, oxytetracycline, spectinomycin, streptomycin, tetracycline, trimethoprim/sulfamethoxazole was tested.

The results of this study suggest a multi-drug resistance pattern among the A. hydrophila isolates. All the isolates were resistant to amoxicillin (100\%), ampicillin (100\%), cephalexin $(100 \%)$ and erythromycin $(100 \%)$. The lowest level of resistance was found against florfenicol (4.55\%), gentamycin $(4.55 \%)$, kanamycin $(4.55 \%)$, but susceptibility was recorded to enrofloxacin, neomycin and trimethoprim/sulfamethoxazole. A. salmonicida isolates were resistant to oxytetracycline $(9.38 \%)$ and tetracycline $(9.38 \%)$. For other antibiotics $A$. salmonicida isolates were susceptible. Key words: Aeromonas spp., antibiotics resistance, sea trout, aquaculture, fish pathogen.
\end{abstract}

\section{Introduction}

Aquaculture is one of the fastest developing sectors in the global food industry (FAO, 2016). A new record was reached on the quantity of fish consumption - it has risen to above $20 \mathrm{~kg}$ per capita in 2014. Currently, aquaculture produces half of the all fish consumed by humans (FAO, 2016).

The most significant diseases in fish hatcheries are caused by bacteria (Briede, 2010). The Aeromonas spp. are the dominant fish bacterial infectious agents in Europe, as well as in Latvia, which causes economically significant losses in cultivated salmonids in fresh and marine waters (Briede, 2010; Toranzo, Magarinos, \& Romalde, 2005). It also affects a variety of non-salmonid fish and shows a widespread distribution (Briede, 2010; Toranzo, Magarinos, \& Romalde, 2005). Due to inadequate personal hygiene and poor quality of water, mainly in developing countries in different parts of the world, Aeromonas spp. have been associated both to foodborne and water-borne diseases (Ahmad \& Odeyemi, 2014; Odeyemi \& Ahmad, 2017).

Aeromonas spp. are ubiquitous bacteria in terrestrial and aquatic milieus (Igbinosa et al., 2012). In salmonids, they are renowned as enteric pathogens causing hemorrhagic septicemia, fin rot, soft tissue rot and furunculosis resulting in major die-offs and fish kills (Fečkaninová et al., 2017).

A. salmonicida mainly affects salmonid fish, causing high mortality rate in the Atlantic salmon (Salmo salar) and the rainbow trout (Oncorhynchus mykis) (Fernández-Álvareza et al., 2016). In salmonids, different clinical presentations of the disease, varying from acute to chronic as well as subclinical form, have been described (Coscelli et al., 2014). According to statistics, the mortality caused by this disease can reach a high of nearly $100 \%$, resulting in heavy marked-economic losses (Liu, 2017).

Motile aeromonad infection is probably the most common bacterial disease of freshwater fish (Fečkaninová et al., 2017). By far the most important fish pathogen is $A$. hydrophila. Clinical signs of $A$. hydrophila infection range from superficial to deep skin lesions, to a typical, gram-negative bacterial septicemia, with or without skin lesions. The disease is often associated with serious damage and economic losses in rainbow trout farming industry (Fečkaninová et al., 2017).

Indiscriminate and comprehensive use of antibiotics to prevent and treat bacterial diseases and the application of subtherapeutic dose of antibiotics have induced a global increase in antibiotic resistance among pathogenic bacteria (Hernández Serrano, 2005; Vivekanandhan et al., 2002). Therefore, the aim of this study was to investigate antibiotic resistance patterns of Aeromonas spp. isolated from the sea trout (Salmo trutta) from the state fish hatcheries.

\section{Materials and Methods}

Study site and sampling

Investigations were performed in four fish hatcheries of the Institute of Food Safety, Animal 
Health and Environment 'BIOR' in the main Latvian river drainage basins of the Daugava, Venta and Gauja during the five year period $(2012$ - 2016). In all these hatcheries fish are reared in the flow-through systems. Sea trout of different age groups were used in our research: fry, one year old parr and smolt $(\mathrm{n}=$ 52). Live sea trout was brought to the Animal Disease Diagnostic Laboratory of the Institute of Food Safety, Animal Health and Environment 'BIOR'. Sampling was done 9 times during the 5-year period: in May 2012, 2 times in June 2014, August 2015, 2 times in April, June, August and September 2016.

For processing the received data, the percentage deductions were used.

\section{Isolation and identification of the bacteria}

The material for bacteriological investigations from ulcers of the skin and from the internal organs: liver, kidney, heart and spleen, aseptically were sampled from fishes with the clinical signs. Samples were cultured, according to standard bacteriological method by direct cultivation on the double set of plates with a culture medium consisting of Tryptone soya agar, Blood agar and MacConkey agar (Biolife, Italy). The plates were incubated in aerobic conditions: one set of plates at $22{ }^{\circ} \mathrm{C}$ and the other set at $37^{\circ} \mathrm{C}$ for $24-48 \mathrm{~h}$.

The microorganisms that showed typical colony morphology of Aeromonas spp. were sub-cultured on double set of plates with Tryptone soya agar, Blood agar and MacConkey agar, respectively, incubated at $22^{\circ} \mathrm{C}$ and $37^{\circ} \mathrm{C}$ in the aerobic conditions for $24-48$ $\mathrm{h}$, until the pure culture with homogenous colonies was obtained.

Identification of Aeromonas species was based on the colony morphology, microscopic appearance, a positive oxidase and catalase reactions, growth on MacConkey agar and fermentation of carbohydrates. For confirmation and species identification of Aeromonas spp., a standardized system for the identification of non-fastidious and non-enteric Gramnegative rods - API 20NE - was applied (BioMérieux, France).

\section{Antimicrobial susceptibility testing}

One isolate of Aeromonas spp. from each sample that had been identified to the species level was selected for the determination of antimicrobial susceptibility. The antimicrobial susceptibility testing was performed according to the standard of Clinical and Laboratory Standards Institute (Miller et al., 2010) using the disk diffusion method. The following antimicrobial paper disks (Bio-Rad, USA) impregnated with a defined concentration of antimicrobial agent were used to determine the antimicrobial susceptibility of the isolates: Amoxicillin $(25 \mu \mathrm{g})$, Doxycycline
$(30 \mu \mathrm{g})$, Erythromycin $(15 \mu \mathrm{g})$, Florfenicol $(30 \mu \mathrm{g})$, Gentamycin $(10 \mu \mathrm{g})$, Kanamycin $(30 \mu \mathrm{g})$, Lincomycin $(15 \mu \mathrm{g})$, Neomycin (30 IU), Oxytetracycline $(30 \mu \mathrm{g})$, Spectinomycin $(100 \mu \mathrm{g})$, Streptomycin $(10 \mu \mathrm{g})$ and Tetracycline $(30 \mu \mathrm{g})$.

For antimicrobial susceptibility testing the 2-3 bacterial colonies from Tryptone soya agar with a loopful $(1 \mu 1)$ were transferred and suspended in 5 $\mathrm{ml}$ Tryptic-soya broth (Biolife, Italy). The density of the bacterial suspension, according to MacFarland 0.5 , was controlled using a densitometer (Sensititre, TREK Diagnostic Systems Ltd.). The adjusted inoculum suspension was streaked on Mueller Hinton agar plates $(\varnothing 90 \mathrm{~mm})$ using a sterile cotton swab on an applicator. After 3-5 minutes, when excess surface moisture had been absorbed by agar, the antimicrobial disks were positioned on the inoculated agar surface using 6-Disk dispenser (Bio-Rad, USA). The plates were incubated for $24 \mathrm{~h}$, respectively, for the detection of antimicrobial resistance of $A$. salmonicida at $22{ }^{\circ} \mathrm{C}$ for and for A. hydrophila at $37^{\circ} \mathrm{C}$. The diameter of the inhibition zones was measured (mm), after the incubation and expounded as susceptible, intermediate or resistant according to the CLSI breakpoints and the manufacturer instructions.

\section{Results and Discussion}

The investigations from 2012 to 2016 demonstrated that the sea trouts from the free river drainage basins have been exposed to Aeromonas spp. (Table 1). Most often we isolated A. salmonicida (42.31\%, Figure 1). In the case of A. hydrophila, the prevalence was $23.08 \%$. The mixed infections by A. hydrophila and A. salmonicida were observed in $19.23 \%$ of the examined fish. In $15.38 \%$ Aeromonas spp. were not detected.

Briede (2010) reported Flexibacter spp., A. salmonicida and A. hydrophila, as the main isolated bacteria groups from fishes with the clinical manifestations of disease in Latvia. Similar results were obtained by Medne \& Liepins (2004). Aeromonosis of the sea trout has been ascertained in the state fish hatcheries on the Daugava and Gauja river drainage basins. The bacteriological studies demonstrated that fish sampled from the Gauja and Daugava river drainage basins showed more affirmative results for Aeromonads. It may be occasionally that the Daugava and Gauja river drainage basins were more polluted by bacteria that can induce the disease (Briede, 2010). In the Daugava river there were three salmonid fish hatcheries downstream one another which supposedly allowed the infection to travel between hatcheries, causing the disease outbreaks even in the most distant hatchery (Briede, 2010).

The disease outbreaks occurred more often in the spring - summer period when the water temperature 
Positive results for $\boldsymbol{A}$. hydrophila and $\boldsymbol{A}$. salmonicida in sea trout from river drainage basins

\begin{tabular}{|c|c|c|c|c|c|c|}
\hline \multicolumn{7}{|c|}{ River basin } \\
\hline & Daugava & \multicolumn{2}{|c|}{ Venta } & \multicolumn{3}{|c|}{ Gauja } \\
\hline Year & 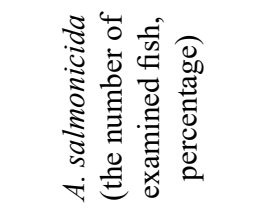 & 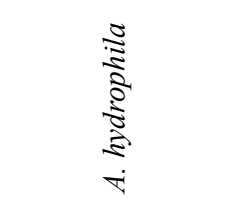 & 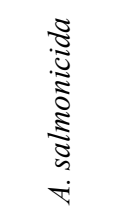 & $\begin{array}{c}\frac{1}{2} \\
3 \\
\frac{3}{3} \\
\frac{3}{3} \\
0\end{array}$ & 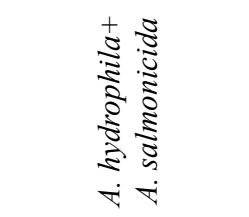 & 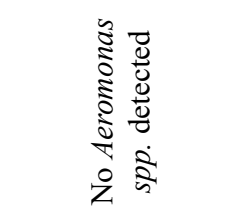 \\
\hline 2012 & & & & & $1(\mathrm{n}=10,19.23 \%)$ & \\
\hline 2014 & $2(n=14,26.92 \%)$ & & & & & \\
\hline 2015 & & $1(\mathrm{n}=1,1.92 \%)$ & & & & \\
\hline 2016 & $1(\mathrm{n}=3,5.76 \%)$ & & $\begin{array}{c}1(\mathrm{n}=5, \\
9.62 \%)\end{array}$ & $\begin{array}{c}2(\mathrm{n}=11, \\
21.15 \%)\end{array}$ & & $1(\mathrm{n}=8,15.38 \%)$ \\
\hline Total & \multicolumn{6}{|c|}{9 samplings $(\mathrm{n}=52,100 \%)$} \\
\hline
\end{tabular}

was above $+20^{\circ} \mathrm{C}$ (Medne \& Liepins, 2004; Briede, 2010).

The percentage of $A$. hydrophila isolates demonstrating resistance against specific antibiotic is given in Table 2. The obtained result revealed a high level of multi antibiotic resistance among the isolates. A. hydrophila were resistant to amoxicillin, ampicillin, cephalexin and erythromycin.

Resistance to $\beta$-lactam antibiotics also was reported by Odeyemi \& Ahmad (2017) and Vivekanandhan et al. (2002). They claimed that all $A$. hydrophila isolates of fish were resistant to ampicillin and methicillin. Resistance to these drugs is chromosomally mediated, but is sometimes caused by plasmids or integrons. The frequent use of antibiotics to treat Aeromonas infections often results in the increased levels of antimicrobial drug resistance (Strateva, Olumide, \& Odeyemi, 2016).

In our research more than $90 \%$ of the $A$. hydrophila isolates were resistant to lincomycin and oxytetracycline. Half of the isolates were resistant to tetracycline. Different authors reported about $A$. hydrophila tetracycline resistant strains (Vivekanandhan, 2002; Penders \& Stobberingh, 2008). In some previous studies on antibiotic resistance in aquaculture found frequencies of oxytetracyclineresistant Aeromonas spp. similar to our results: rainbow trout in Denmark (oxytetracycline resistance found in $69 \%$ cases); catfish in the USA (tetracycline resistance found in $46 \%$ cases); and catfish in the USA (oxytetracycline resistance as high as 62\%; tetracycline resistance 43\%) (Penders \& Stobberingh, 2008).

Kanamycin and neomycin were the other antibiotics, to which a low frequency of resistance was noticed (Table 2). In contrast, Vivekanandhan et al. (2002) observed a high frequency of Aeromonas spp. antibiotic resistant strains.

$4.55 \%$ of $A$. hydrophila strains from the sea trout were established resistant to gentamycin.

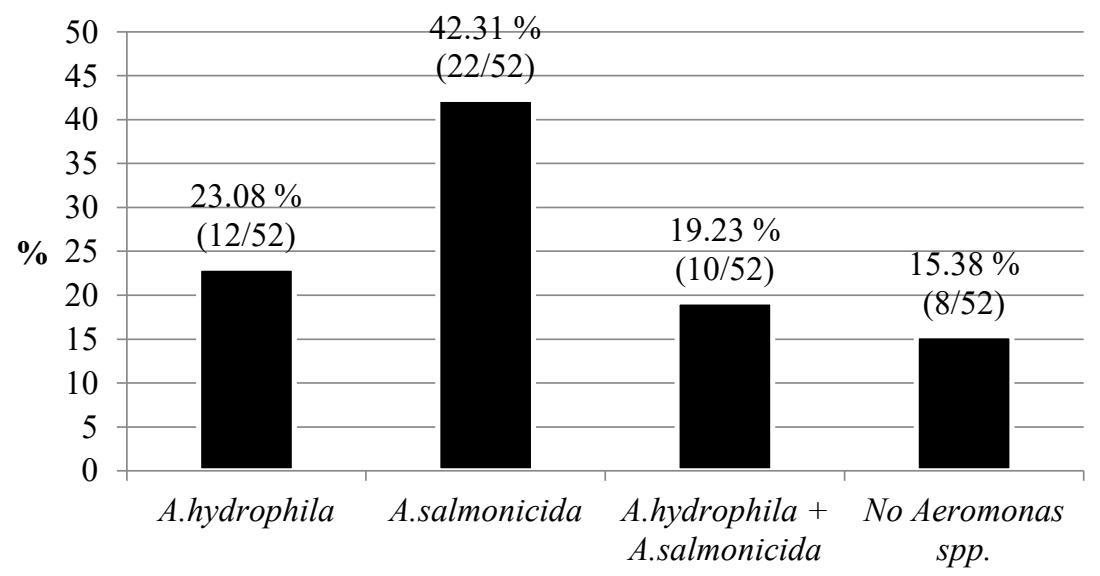

Figure 1. Relative occurrence of Aeromonas spp. 
Frequency of antibiotic resistant $A$. hydrophila and $A$. salmonicida isolates from the sea trout

\begin{tabular}{|l|c|c|}
\hline \multicolumn{1}{|c|}{ Antibiotics } & A. hydrophila $(\mathrm{n}=22)$ & A. salmonicida $(\mathrm{n}=32)$ \\
\hline Amoxicillin & 100.0 & 0 \\
\hline Ampicillin & 100.0 & 0 \\
\hline Cephalexin & 100.0 & 0 \\
\hline Colistin & - & 0 \\
\hline Doxycycline & 50.0 & 0 \\
\hline Enrofloxacin & 0 & - \\
\hline Erythromycin & 100.0 & 0 \\
\hline Florfenicol & 4.55 & 0 \\
\hline Gentamycin & 4.55 & 0 \\
\hline Kanamycin & 4.55 & - \\
\hline Lincomycin & 91.67 & 0 \\
\hline Neomycin & 0 & 9.38 \\
\hline Oxytetracycline & 91.67 & 0 \\
\hline Spectinomycin & 9.09 & 0 \\
\hline Streptomycin & 10.0 & 9.38 \\
\hline Tetracycline & 50.0 & 0 \\
\hline Trimethoprim-sulfamethoxazole & 0 & \\
\hline
\end{tabular}

Vivekanandhan et al. (2002) reported that $8.2 \%$ of the A. hydrophila strains isolated from fish with the clinical signs and healthy fish demonstrated resistance to this antibiotic, which was not considerably higher than the resistance found in our research (Vivekanandhan et al., 2002).

The least resistance was observed to florfenicol (4.55\%), gentamycin (4.55\%), kanamycin (4.55\%) spectinomycin $(9.09 \%)$ and streptomycin (10\%). Similar results were obtained by Odeyemi et al. (2017), who reported that the least resistance was to aminoglycosides. All of $A$. hydrophila isolates were susceptible to enrofloxacin, neomycin, trimethoprim/ sulfamethoxazole.

The frequency of $A$. salmonicida resistance against each antibiotic is shown in Table 2. A. salmonicida showed the prevalence of resistance to oxytetracycline $(9.38 \%)$ and tetracycline $(9.38 \%)$. In regard to other antibiotics $A$. salmonicida isolates were susceptible.

Nowadays an increase in the levels of resistance of A. hydrophila strains to commonly used antibacterial agents (penicillins and cephalosporins) has been observed (Vivekanandhan et al., 2002). It is believed that the greatest potential risk to public health associated with the use of antimicrobial agents in aquaculture is the creation of a reservoir of transferable resistant genes in bacteria in aquatic environments from which such genes can be spread by horizontal transfer of genes to other bacteria and ultimately reach human pathogens (Smith, 2008). This is confirmed by other studies on antibiotic resistance of Aeromonas spp. (Hernández Serrano, 2005).

As a result of the growing realization that antibiotics should be used with greater caution, there is a trend towards stricter antibiotic regulations in the aquaculture sector and the presence of antibiotic residues in aquaculture products. In some countries (specifically Europe, North America and Japan), regulations on the use of antibiotics are strict and only a few antibiotics are licensed for the use in aquaculture (Defoirdt, 2011).

It is therefore essential to conduct further surveillance and control on bacterial resistance in fish. There is a need for further study on antibiotic resistance to Aeromonads from other salmonids.

\section{Conclusions}

The results of the research show that in the state fish hatcheries of the Institute of Food Safety, Animal Health and Environment 'BIOR', Latvia Aeromonas spp. are present. A. hydrophila $23.08 \%$ and $A$. salmonicida $42.31 \%$ were isolated most often. The results confirm the presence of multi antibiotic resistant Aeromonas spp. isolated from the sea trout in Latvia. A. hydrophila were resistant to amoxicillin, ampicillin, cephalexin and erythromycin. A. salmonicida showed resistance to oxytetracycline $(9.38 \%)$ and tetracycline $(9.38 \%)$. 


\section{Acknowledgements}

The authors are thankful to the Institute of Food Safety, Animal Health and Environment BIOR. This study was supported by National Research
Programme - Agricultural Resources for Sustainable Production of Qualitative and Healthy Foods in Latvia (AgroBioRes).

\section{References}

1. Ahmad, A., \& Odeyemi, O.A. (2014). Anti-biogram and resistogram profiling of Aeromonas species isolated from Malaysian coastal seawater. Pollution Research. Volume 33 (issue 2), 487 - 492. DOI: 10.1016/j.sjbs.2015.09.016.

2. Briede, I. (2010). The actual fish diseases in Latvia. Acta Biol. Univ. Daugavp., Volume 10 (issue 2), $137-142$.

3. Coscelli, G.A., Bermúdez, R., Losada, A.P., Faílde, L.D., Santosa, Y., \& Quirog, M.I. (2014). Acute Aeromonas salmonicida infection in turbot (Scophthalmus maximus L.). Histopathological and immunohistochemical studies. Aquaculture. Volume 430, 79-85. DOI: 10.1016/j.aquaculture.2014.04.002.

4. Defoirdt, T., Sorgeloos, P., \& Bossier, P. (2011). Alternatives to antibiotics for the control of bacterial disease in aquaculture. Current Opinion in Microbiology. Volume 14, 251 - 258. DOI: 10.1016/j.mib.2011.03.004.

5. Fečkaninová, A., Koščová, J., Mudroňová, D., Popelka, P., \& Toropilová, J. (2016). The use of probiotic bacteria against Aeromonas infections in salmonid aquaculture. Aquaculture. Volume 469, $1-8$. DOI: 10.1016/j.aquaculture.2016.11.042.

6. Fernández-Álvareza, C., Gijón, D., Álvarez, M., \& Santosa, Y. (2016). First isolation of Aeromonas salmonicida subspecies salmonicida from diseased sea bass, Dicentrarchus labrax (L.), cultured in Spain. Aquaculture Reports. Volume 4, 36 - 41. DOI: 10.1016/j.aqrep.2016.05.006.

7. Hernández Serrano, P. (2005). Responsible use of antibiotics in aquaculture. FAO Fisheries Technical Paper. No. 469. Rome: FAO.

8. Igbinosa, I., Igumbor, E., Aghdasi, F., Tom, M., \& Okoh, A. (2012). Emerging aeromonas species infections and their significance in public health. The Scientific World Journal. Volume 2012, 13 pages. DOI: $10.1100 / 2012 / 625023$.

9. Liu, P., Du, Y., Meng L., Li, X., \& Liu, Y. (2017). Proteomic analysis in kidneys of Atlantic salmon infected with Aeromonas salmonicida by iTRAQ. Developmental \& Comparative Immunology. Volume 72, $140-$ 153. DOI: 10.1016/j.dci.2017.02.013.

10. Medne, R., \& Liepins, E. (2004). Microorganisms isolated from affected tissue in case of fin necrosis. In International scientific conference 'Animals. Health. Food hygiene', 15 October 2004 (pp. 196 - 200) Jelgava, Latvia.

11. Miller, R.A, Carson, J., Dalsgaard, I., Gaunt, P.S., Gieseker, C., Hawke, J.P., Reimschuessel, R., Smith, P.R., Somsiri, T., \& Wu, C.C. (2010). Performance Standarts for Antimicrobial Susceptibility Testing of Bacteria Isotated From Aquatic Animals: First Informational Supplement. Clinical and Laboratory Standards Institute.

12. Odeyemi, A.O., \& Ahmad, A. (2017). Antibiotic resistance profiling and phenotyping of Aeromonas species isolated from aquatic sources. Saudi Journal of Biological Sciences. Volume 24 (issue 1), $65-70$. DOI: 10.1016/j.sjbs.2015.09.016.

13. Penders, J., \& Stobberingh, E.E. (2008). Antibiotic resistance of motile aeromonads in indoor catfish and eel farms in the southern part of The Netherlands. International Journal of Antimicrobial Agents. Volume 31 (issue 3), 261 - 265. DOI: 10.1016/j.ijantimicag.2007.10.002.

14. Smith, P. (2008). Antimicrobial resistance in aquaculture. Revue scientifique et technique (International Office of Epizootics). Volume 27 (issue 1), $243-264$.

15. Strateva, D., Olumide, A., \& Odeyemi, A. (2016). Antimicrobial resistance of Aeromonas hydrophila isolated from different food sources: A mini-review. Journal of Infection and Public Health. Volume 9 (issue 5), 535 - 544. DOI: 10.1016/j.jiph.2015.10.006.

16. The State of World Fisheries and Aquaculture 2016. Contributing to food security and nutrition for all. (2016) Rome: FAO.

17. Toranzo, A.E., Magarinos, B., \& Romalde, J.L. (2005). A review of the main bacterial fish diseases in mariculture systems. Aquaculture. Volume 246, 37 - 61. DOI: 10.1016/j.aquaculture.2005.01.002.

18. Vivekanandhan, G., Savithamani, K., \& Hatha, A.A.M., Lakshmanaperumalsamy, P. (2002). Antibiotic resistance of Aeromonas hydrophila isolated from marketed fish and prawn of South India. International Journal of Food Microbiology. Volume 76, 165 - 168. DOI: 10.1016/S0168-1605(02)00009-0. 